\title{
POST-SOVIET TRADE AND INSTITUTIONAL QUALITY: SUBNATIONAL EVIDENCE
}

\section{A. Libman}

Alexander Libman - PhD (Economics), Doctor of Economic Sciences, Professor of Social Sciences and Eastern European Studies. Ludwig Maximilian University of Munich, Konradstraße 6, 80801 Munich, Germany. E-mail: alexander.libman@soziologie.uni-muenchen.de.

ORCID: 0000-0001-8504-3007

Abstract: The paper aims to investigate the impact of the dependence on the post-Soviet trade on the quality of economic institutions in the Russian subnational regions. For this purpose, it uses two approaches: it looks at how the effect of post-Soviet trade on growth changes over time (hypothesizing that if one observes the decline of this effect, the latter is more likely to be driven by the legacy of the Soviet economy and thus less conducive for the improvement of institutional quality) and at the correlation of post-Soviet trade and quantitative indicators of the quality of economic institutions. The results suggest that the post-Soviet trade is more likely to have a positive impact on the institutional change. Specifically, I find that regions of Russia with a larger share of the post-Soviet trade in the total international trade turnover, are characterized by persistently higher growth rates than other regions throughout the period of investigation (2001-2012). Furthermore, I find that the quantitative measures of the quality of economic institutions in the Russian regions exhibit, if any, a positive correlation with the share of the post-Soviet trade. The effect observed could be linked to the complexity of the regional economies and to the substantial presence of new market-based ties in the post-Soviet trade flows.

Keywords: foreign trade, quality of institutions, Russian regions, post-Soviet space

For citation: Libman A. Post-Soviet Trade and Institutional Quality: Subnational Evidence. Prostranstvennaya Ekonomika = Spatial Economics, 2018, no. 3, pp. 115-137. DOI: 10.14530/ se.2018.3.115-137.

\section{INTRODUCTION}

The start of transition in the post-Soviet Eurasia was marked not only by the collapse of the old political and economic system, but also by the disappearance of the very polity, which defined this space, - the USSR. This implied that, for new independent states and their subnational regions, a crucial factor explaining the limits of institutional design they could have implemented emerged - the extent

(C) Libman A., 2018 
to which their economies remained dependent on the old economic ties, which persisted after the collapse of the Soviet Union. In some parts of the post-Soviet Eurasia, these ties quickly disappeared; in others, they remained highly robust. However, the role of the economic ties between countries of Eurasia as factors of the policy choice at the national and subnational levels remains understudied.

This paper aims to contribute to this discussion by focusing on how trade dependence on the former Soviet states affected the variation of paths of institutional change among regions of the Russian Federation. "Trade" in this context refers to cross-border exchange of goods between the regions of the Russian Federation and the post-Soviet countries. Thus, I look at the international trade, but on the Russian side I disaggregate it to see to which extent individual Russian regions participate in it. In the post-Soviet context, international trade encompasses two types of trade flows: those based on the old Soviet ties and complementarities and those based on the market competition. The paper studies the relative importance of these types of flows for individual regions (i.e., in which regions agents based on Soviet complementarities generate the lion's share of international trade flows, and in which regions agents operating on market competition principles do it), and how these differences affect the quality of economic institutions, which emerge in the region.

While talking about regions, throughout the paper, I refer to the constituent subjects of the Russian Federation (sub"ekty Rossiyskoy Federatsii): oblast, kray, republic, autonomous oblast and okrug, and federal cities. In Russia, there exists substantial variation in the quality of institutions - both formal and informal - at the subnational level (Granville, 2010; Bruno, Bytchkova, Estrin, 2013; Yakovlev, Zhuravskaya, 2013). Methodologically, comparing regions rather than countries reduces unobserved heterogeneity and thus improves the quality of econometric investigation. Thus, studying the subnational dimension of the impact of trade with post-Soviet countries on the institutional quality is a promising avenue for research. I use two approaches to research the link between the post-Soviet trade and the quality of institutions in the regions of Russia. The first is an indirect one and looks at how post-Soviet trade influence on growth in regions of Russia changes over time. The second approach is based on the direct analysis of comovement of various indicators of institutional quality in the regions of Russia and their trade with the post-Soviet countries.

\section{SPECIFICS OF THE POST-SOVIET TRADE DEPENDENCY}

The Soviet model of the planned economy resulted in development of intensive economic connections between union republics. This was due to, on the one hand, the demand for autarky from the Soviet leadership, which undertook 
substantial effort to avoid dependence on supply from abroad, and, on the other hand, the intent to prevent formation of isolated regional economies in the USSR. Unlike China, where the central authorities in the Maoist era endorsed the idea of self-sustaining provincial economies (Donnithorne, 1972), in the USSR the experiments with strengthening the subnational level of economic decision making ceased already in the 1960s after the Khrushchev's sovnarkhoz reform was abandoned: the dominance of functional hierarchies (ministries and agencies) resulted into development of supply chains systematically crossing the borders of individual Soviet republics. In many cases, the only supplier producing inputs or delivering raw material for a particular factory was located in a different Soviet republic, with the equipment tailored to use only inputs provided by this supplier.

The dissolution of the Soviet Union disrupted this network of interconnections. On the one hand, the general collapse of the institutions of the planned economy left economic actors unable to transact with each other: enterprises had no way to find possible partners, no experience in organizing and implementing deals on their own. On the other hand, individual post-Soviet countries introduced a multitude of protectionist measures, designed to generate fiscal revenue and to respond to the demands of the lobbyists. Over time, especially after the end of the transition recession of the 1990s was over, many companies managed to establish new economic ties outside the post-Soviet area. At the same time, new economic connections between former Soviet countries came into existence, this time driven primarily by market forces. Strong social ties between the countries of the post-Soviet Eurasia and the presence of Russian as the lingua franca made post-Soviet Eurasia an attractive choice for many Russian companies pursuing an internationalization strategy (Kheyfets, 2011).

The development of economic ties in the post-Soviet Eurasia over time, however, was not uniform - not only for individual countries, but also for individual regions within the Russian Federation. This is hardly surprising: differences in economic connections should have arisen because of differences in the industrial structure and in the geographic location. Some Russian regions exhibited strong dependence on supplies from the post-Soviet countries (like Ivanovo Oblast, for which cotton from Central Asia remained a crucial input for its textiles industry). Some regions profited from the post-Soviet trade because of their border location (although, as Vardomskiy (2017) shows, the extent to which individual border regions actually were able to maintain and develop trade ties with their neighbors differed a lot).

Economic ties (in particular, trade) between the post-Soviet states and Russia share a number of common characteristics, which make them distinct from how international trade is typically perceived and analyzed in the scholarly literature. 
To start with, as mentioned, in many cases trade emerged out of bilateral monopoly relations, which existed in the Soviet era. While the importance of the Sovietera sunk costs goes down over time, it still remains very high in some of the industries. It means that many non-competitive sectors, which would not survive in a global economy, have a chance in the post-Soviet trade, which is frequently used to keep the monopoly positions of the Soviet era intact (Yevstigneev 1997). More importantly, second, post-Soviet trade is in many cases heavily influenced by politics. Some of the countries of the former Soviet Union kept the main part of their economy under governmental control; in this case (e.g., in dealing with Belarus or Uzbekistan), political involvement becomes a mandatory precondition for business transactions. On the Russian side, the political actor involved in the decision-making is in many cases the regional governor, who can use the transactions to extract rents. Certainly, it would be too simplistic to argue that the entire post-Soviet trade requires political connections to happen. For example, there are examples of vivid informal cross-border trade, which, as it is usually the case, happens outside of any governmental control. However, the importance of transactions happening with a strong involvement of politics should be underestimated.

These specific characteristics of the post-Soviet trade (role of politics and dependence on old technological complementarities) are likely to determine how the post-Soviet trade affects institutional and political development in the regions of Russia. Indeed, the extant literature provides evidence for a number of distinct characteristics of the Russian regions associated with high dependence on the post-Soviet trade ties - mostly for the early 2000 s, but also for the first decade of the $2000 \mathrm{~s}$.

\section{PREVIOUS EVIDENCE: POLITICS AND GROWTH}

The existing research concentrated primarily on two characteristics of the regions of Russia. First, it looks at the differences between regions in terms of economic growth. Libman and Obydenkova (2014) show that regions of Russia, which exhibit higher share of international trade with the post-Soviet space, are also, ceteris paribus (in particular controlling for the overall foreign trade dependence) characterized by higher growth rates, looking at the period of 2000 2006. Libman (2013) demonstrates that the positive effect is associated primarily with trade with Central Asian countries and not with Ukraine. This result confirms that the old Soviet ties - especially given the importance of technological complementarities - remain a crucial factor sustaining economic performance in Russia. Regions, which managed to maintain stronger trade ties to the former Soviet Union countries, suffered from the so-called 'disorganization' (Blanchard, 
Kremer, 1997) of the 1990s to the lesser extent, and thus were able to demonstrate higher growth in the 2000s.

This result, while important, allows for ambiguous interpretations in terms of the effect of the post-Soviet trade on the institutional change - the transformation of formal and informal economic institutions. If the trade preserves old inefficient economic patterns established during the era of the planned economy, its high share in the overall international trade could actually be seen as evidence of region's underperformance in terms of creating institutions favoring the development of the markets. In this case, the positive effect of the post-Soviet trade on growth is simply part of the 'disappearing' Soviet reality, which may give some regions advantage during the transition period, but should have adverse effect in the long run. While at the beginning of transition, regions with more advanced market institutions find themselves at a disadvantage because of the lack of experience of companies regarding the operation of these institutions and numerous loopholes and issues, which still have to be resolved, over time this disadvantage disappears - and then these regions can benefit from the ability of the market competition to operate as a Hayekian discovery process, allowing them to gradually establish a superior structure of economic ties. Regions with less successful institutional development, while benefit from it in the early years of transition (because their economies do not have to bear the costs of adaptation), ultimately remain 'stuck' in the old inefficient economic ties of the planned economy. Furthermore, their companies do not need to undergo costly modernization because of their privileged access to old markets in the former Soviet republics (based on technological complementarities and cultural similarities) protecting them from competition ${ }^{1}$.

The negative interpretation of the effects of the post-Soviet trade also fits another piece of empirical evidence, reported by Obydenkova and Libman (2012) for 2000-2006 and Obydenkova and Libman (2015) for the first decade of the 2000s. An important feature of Russian regions is that they differ not only in terms of economic institutions, but also in terms of their political organization. Russia, as many other large federations in the developing world, combines regions with higher and lower levels of political pluralism (Gel'man, 1999). This variation of political regimes appears to be strongly linked to the differences in the extent to which regions depend on the post-Soviet trade: regions, which have a relatively higher share of post-Soviet countries in their foreign trade turnover, are less pluralist and competitive politically. The negative effect goes down if regions exhibit more intensive interaction with the EU, e. g., participate in joint projects and initiatives (Lankina et al., 2016).

${ }^{1}$ On the opposite, using old technologies (which are not competitive internationally) is actually an advantage for businesses. 
This effect of the post-Soviet trade on political institutions can be explained by two mechanisms. On the one hand, many of the crucial trade partners of the Russian regions in the post-Soviet Eurasia are consolidated non-democracies. Since the post-Soviet trade is heavily politicized, it involves regular contacts between regional elites and elites of the post-Soviet countries they trade with. These contacts create fruitful background for informal interaction and learning effects. While the literature suggests that trade with democracies creates learning effects strengthening democratic regimes (Sandholtz, Koetzle, 2000), trade with autocracies should have an opposite effect (Tansey et al., 2017). The second mechanism is an indirect consequence of the institutional complementarities post-Soviet trade is based on. Because of those, companies in many regions are crucially dependent upon receiving supplies and raw material from the postSoviet countries: there are no immediate substitutes. But these supplies can be accessed only through deals with a strong political participation. As a result, political actors become gatekeepers, restricting access to crucial goods for the development of the regional companies. They exchange this gatekeeper function for political support from the regional business.

The negative effect of post-Soviet trade on political pluralism is rather an argument against the ability of post-Soviet trade to contribute to the improvement of quality of economic institutions. Throughout the world, the link between economic and political liberalization is, generally speaking, ambiguous, but in Central and Eastern Europe and in the post-Soviet Eurasia it is positive (Fidrmuc, 2003). Russian regional regimes rarely turn into Chinese-style developmental states; more often they function as rent-seeking 'grabbing hand' regimes with negative implications for their economies. Given the mechanism of the consolidation of power I have described, governments will probably have a particularly strong incentive not to pursue systematic institutional reforms: it is important for them to keep the existing model of dependence of business on the post-Soviet trade intact.

However, while the empirical research gives some reasons to believe that dependence on the Soviet trade should result in poor quality of economic institutions, theoretically, the question is much more ambiguous, as the next section will show.

\section{POST-SOVIET TRADE AND QUALITY OF ECONOMIC INSTITUTIONS}

Generally speaking, it is possible to devise both arguments in favor and against the ability of the post-Soviet trade to contribute to the improvement of quality of economic institutions. The negative effects of the post-Soviet trade 
on institutional quality could be linked to three factors, which I have partially mentioned above. First, post-Soviet trade is a product of planned economy and, as such, most likely less efficient than a structure free market would produce. One can hypothesize that if the links of the post-Soviet trade are more persistent, it means that the likelihood that the regional economy will conserve the old Soviet structures and patterns is higher. In this case, the business demand for improvement of economic institutions in the region should be low: there is no additional value for them except potentially creating more competition and disrupting the existing ties. Somewhat simplified, the dependence on the postSoviet trade could constitute what Polterovich (1999) refers to as an 'institutional trap'. Even if the institutional innovations were introduced by the government, they would most likely clash with the informal institutions, which would thus undermine the success of institutional change.

Second, high involvement of political actors in the post-Soviet trade relations could affect not only the behavior of regional governments (as the previous research has shown), but also the behavior of business actors. Companies which prosper under these conditions have to invest substantial effort into establishing good connections to the regional governments; thus, they are unlikely to support any change in the institutional environment, if it reduces the value of this investment. The argument that politically connected companies are actually interested in preserving inefficient institutions to protect their competitive advantage is well-established in the literature on the post-Soviet world (Guriev, Sonin, 2009). Whether this effect is present or not depends, on the one hand, on the risk of expropriation, which is inevitably linked with poor quality of economic institutions even for the companies with the highest level of political connections, and, on the other hand, on the relative benefits companies extract from political connections and from a possible economic liberalization (Marshall. Stone, 2011). The more companies concentrate on political connections as the main strategy of their survival, the more attractive it becomes for other companies to do the same (and the costlier it becomes not to implement similar policies) (Gaddy, Ickes, 1999). Again, high dependence on post-Soviet trade could lead to such an equilibrium outcome.

Third, the negative effect of the post-Soviet trade dependence on political pluralism could limit the presence of Western companies on the regional markets. From their point of view, these regions (with some exceptions) could be too risky to engage with (Ledyaeva et al., 2013) ${ }^{1}$. As a result, potentially, an important actor both directly (through lobbying) and indirectly (through transferring business practices) positively influencing the quality of economic institutions should be

${ }^{1}$ Note that this argument is disputed: Stoner-Weiss (2000) suggests exactly the opposite link between political pluralism and the FDI inflow. 
less active in regions with large post-Soviet trade. While the positive effects of Western FDI on the quality of institutions should not be overestimated ex-ante (Western business can also be involved in corruption and focus on using political connections rather than on succeeding in market competition), it is likely that the FDI from the Western countries are on average exercise positive influence on the institutional quality ${ }^{1}$.

At the same time, several arguments suggest that the post-Soviet trade ties could actually improve the quality of economic institutions. The first, and the most obvious, factor to consider is the specific industrial structure of the postSoviet trade as opposed to Russia's trade with other countries. While Russian exports to the EU are dominated by raw materials (with a particularly strong role of oil and gas), post-Soviet Eurasia remains the part of the world, where Russia actively sells its machinery and equipment. While it is able to do so only because of the old Soviet complementarities, the dominance of secondary as opposed to primary sector in the regional economy more actively involved in the postSoviet trade could be a factor triggering demand for better institutions. More sophisticated production chains require larger division of labor, in turn associated with substantial sunk costs and thus a stronger need to protect property rights and ensure the enforcement of contracts. This argument suggests that the already discussed positive effect of post-Soviet trade on economic performance is driven not by the reduction of costs of disorganization, but by a different logic, also forcefully present in the literature: numerous empirical studies suggest that higher sophistication of exports is likely to contribute to economic growth (Rodrick, 2006; Hidalgo, Hausmann, 2009; Poncet, de Waldemar, 2013).

Second, the dominance of political factors in the post-Soviet trade could lead to establishment a powerful group of economic actors, which survives and prospers primarily because of the connections to the countries of the post-Soviet Eurasia. These actors are also most likely to be the source of rents extracted by the regional government. At the same time, beyond this group, there may be more room for the market-driven economic activity; the government, focusing on protecting and expanding its connections to the rent-generating sector governed by informal rules and institutions, could be less inclined to exercise pressure on other companies, not directly connected to the chains of rent-creation and rent-seeking. In the shadow of the government-business symbiosis driven by the post-Soviet trade dependence, new business sectors could emerge. Unlike the rents in the natural resource regions (e. g., those rich in oil and gas), the rents from the post-Soviet trade are never sufficiently large to penetrate the entire regional economy, making the existence of this sector outside the rent-seeking chains more likely.

${ }^{1}$ See also Dairabayeva, Ferrantino, Portugal-Perez and Schmidt (2016) on the effects of FDI on socioeconomic development in Russian regions. 
Third, the nature of the post-Soviet trade should not be oversimplified. Some of the economic ties between the post-Soviet Eurasia and Russia emerged in the 2000 s, are an outcome of the development of markets rather than a continuation of the old Soviet trade ties, and are primarily linked to the consumer goods sector (where similarities in language and consumer habits encourage economic exchange due to the pure market logic). Granted, even this 'market-driven' postSoviet trade is likely to be influenced by political factors (due to the political specifics of the post-Soviet world), but these political factors should not necessarily produce such negative results as those I described above. Besides, at least some of the Eurasian countries (most notably Kazakhstan) in the 2000s have been relatively advanced in terms of their market reforms, which could have again influenced the behavior of Russian business. In the early 2010s, after the establishment of the Customs Union, there was even some evidence of the competition between Kazakhstan and Russia for mobile business able to serve both markets because of the abolition of customs borders, but willing to benefit from more favorable regulatory and fiscal environment in Kazakhstan (Kheyfets, $2015)^{1}$. Finally, it is possible that at least some of the Russian companies viewed Eurasia (which was indeed essential for the internationalization strategies of the Russian business in the 1990s) as the preliminary (and easier) step towards more ambitious internationalization. In this case, high dependence on Eurasian trade should go hand in hand with improvement of business practices.

\section{EMPIRICAL STRATEGY}

In this paper, I use two approaches for studying the effect of the post-Soviet trade on the quality of economic institutions in the Russian regions. The first approach is an indirect one. As mentioned, the post-Soviet trade has a positive effect on economic growth in the regions of Russia. It could be an outcome of the surviving Soviet structures. However, if that is the case, it is plausible to assume that the positive effect of the post-Soviet trade should dissipate over time. The potential of the old structures to sustain economic growth is limited. It could possibly do so in the short run, but over time deficits of the existing structures should make the regions, which still rely on them, lag behind the regions, which experienced more extensive economic transition. But the positive effect on economic growth could also be an outcome of the market-driven 'new' economic ties in Eurasia or of the higher sophistication of exports going to the post-Soviet countries from the Russian regions. If that is the case, the positive

${ }^{1}$ However, Eurasian Development Bank's study (Eurasian..., 2017) suggests that the potential for institutional competition in Eurasia did not materialize to the full extent, primarily because of growing role of the government in the economy. 
effect of the post-Soviet trade on growth should persist over time; and, as the argument above suggests, this is also the case when the positive influence of the post-Soviet trade on the quality of economic institutions becomes more plausible.

The empirical research of this paper looks at the period of 2001-2012. We do not include the period of the 1990s, because the deep economic crisis of that era hardly allowed the companies to venture a strategy of developing new economic ties and breaking from the dependence on the old Soviet complementarities (and if they did, they hardly had time to really benefit from it). It is unlikely that we would observe a significant positive effect of realignment of the region's external economic ties during that era. In the early 2000s, Russia entered a prolonged period of growth. It goes without saying that this growth was to a larger extent driven by the high oil prices than by the improvement of domestic institutions and adaptation of new business practices by Russian companies; but it also would be too simplistic to claim that in the 2000s no positive effects in terms of institutional quality were present in Russia. In the early 2000s, the Russian government managed to implement a number of important reforms, in particular in the area of taxation and jurisprudence. Throughout the 2000s, many Russian companies pursued an active internationalization strategy, which frequently forced them adapting more transparent corporate governance (Heinrich, 2005). If I find that even under these conditions regions with larger share of the postSoviet countries in their foreign trade perform better than other regions, the result can be seen as evidence in favor of a positive link between post-Soviet trade and institutional quality.

We finish our analysis with the year 2012 for two reasons. First, from 2013 on, Russia is in a state of economic stagnation, with the growth rates close to zero. This stagnation appears to be driven by structural and institutional characteristics of the Russian economy. Under these conditions, again, it is unlikely that breaking from the old Soviet trade ties and seeking for new economic opportunities would generate additional potential for economic growth. Second, since 2014, Russian government pursues as systematic import substitution strategy. Some of the postSoviet countries (the members of the Eurasian Economic Union) are to some extent exempt from it (although even they are occasionally treated less favorably than the Russian companies). This, again, could make the test of our conjecture (moving away from old trade ties, if they were inefficient, should improve economic growth, as soon as the disorganization effect wears off) more difficult (see also Apokin et al., 2017).

The second approach directly looks at how trade with the post-Soviet countries co-varies with the quality of institutions in the regions of Russia. I use several quantitative indicators of the institutional quality to look at whether 
regions with high share of international trade with the post-Soviet countries have better or worse economic institutions. Certainly, one has to acknowledge that many of the available indicators are debatable: they represent a particular definition of institutions, focus on certain aspects of institutional quality or use debatable methodology to obtain the value of the indicators. Hence, using a large number of indicators is important, since it allows me to escape the dependence on a particular definitions or concepts. Furthermore, most indicators do not measure institutional quality in all regions of Russia - rather, they look at a particular subsample. It limits my ability to apply multivariate regression analysis, since the number of degrees of freedom is too small. Hence, I have to rely on correlation coefficients, acknowledging a number of obvious drawbacks associated with this approach.

\section{INDIRECT APPROACH: POST-SOVIET TRADE AND ECONOMIC GROWTH OVER TIME}

I start by looking at the indirect evidence, i.e., how the effect of the post-Soviet trade on growth changes over time. For this purpose, I estimate a series of annual cross-sectional regressions $^{1}$ for each year in 2001-2012. The dependent variable is the growth index of the regional GDP corrected for inflation, as reported by the official Russian statistics (Rosstat). The set of controls (rather standard for the empirical research on economic growth) includes the GDP of the year t-1; total fixed capital investments; and the share of the regional population with a university degree ${ }^{2}$. Finally, all regressions also control for the total amount of foreign trade of a region to isolate the possible effect of the post-Soviet trade relations.

The main explanatory variable is the share of the regional trade turnover conducted with the post-Soviet countries in the total international trade turnover. More specifically, Russian statistics reports the indicator of the share of international trade conducted with the CIS countries. I acknowledge that this variable may fail to capture some of the trade flows in the post-Soviet Eurasia. To start with, obviously, it excludes trade with countries, which do not belong to the CIS (like the Baltic states or, after 2009, Georgia). More important are two

${ }^{1}$ I am aware that it is standard in the empirical growth literature to look at the average growth in several years rather than growth in a particular year. I use the presented approach due to the specific objective of the analysis: to understand how the effect of the post-Soviet trade on growth changes over time.

${ }^{2}$ Unlike other indicators, this variable is available not for each year but only for years when the census of the Russian population was conducted: i.e., 2002 and 2010. Thus, I use the data available to the closest time point to the regression I run: for 2002 for 2001-2005 regressions and for 2010 for 2006-2012 regressions. 
other omissions. First, Russian statistical office does not capture a substantial portion of trade flows with Belarus, which occur within the Union State of Russia and Belarus without any customs borders. As a result, the trade I look at primarily happens with Ukraine and Central Asia. Second, in 2010-2012, the data could have been contaminated by another problem: the establishment of the Customs Union of Russia, Belarus and Kazakhstan. The Customs Union abolished customs borders between these countries, but, as a result, the statistical record on the trade within the regional organization became unreliable (the old customs data were not collected anymore and other sources of data were less accurate). Therefore, for this period caution is required while interpreting the data at hand.

One more caveat has to be made concerning the fundamental interpretation of region-level data on international trade. The Russian customs attributes trade flows to a region according to the regional customs office, where they have been processed. Hypothetically, it should be the customs office of the region where the importing or exporting company is located. However, since after the customs clearance there are no legal limitations for Russian companies to forward their goods anywhere else (also to a different branch of the same company located in another region), it is not always the case that the good is indeed used in the economy of the region, which imported it from the statistical point of view (or, conversely, the exported good was actually produced in the region registered as exporter). This problem is present in the cross-national data to a lesser extent than in the subnational ones, since any further transaction involving goods leaving or exiting the territory of an independent country again appears in the customs statistics. I acknowledge this limitation; however, if one uses region-level data (which, as mentioned, are advantageous for many other reasons), there is no way to escape this problem (it is not specific to Russia and is present in any country with a functioning internal market).

The sample of regressions includes all regions except Chechnya and autonomous okrugs. An important problem for studying economic growth in the regions of Russia is the impact of outliers. Some regions of Russia systematically exhibit different patterns of growth than other regions, either due to the statistical peculiarities or because of their unusual economic development. In particular, I exclude three outlier regions in the baseline regressions: Ingushetia, Kalmykia and Chukotka. All three regions seem to exhibit extreme fluctuations in their economic growth patterns and have been excluded from analysis in the previous research (e. g., Libman, 2012). Furthermore, I also run regressions without several other outliers: Cities of Moscow and St. Petersburg and Tyumen Oblast. Furthermore, a set of regressions is estimated excluding the ethnic republics of the Northern Caucasus (Adygeia, Kabardino-Balkaria, Karachaevo-Cherkessia, 
Northern Ossetia and Dagestan - Chechnya and Ingushetia are excluded from the sample already). I also estimate regressions using a sample containing all outliers to understand how strong the impact of abnormal regions on the observed results is.

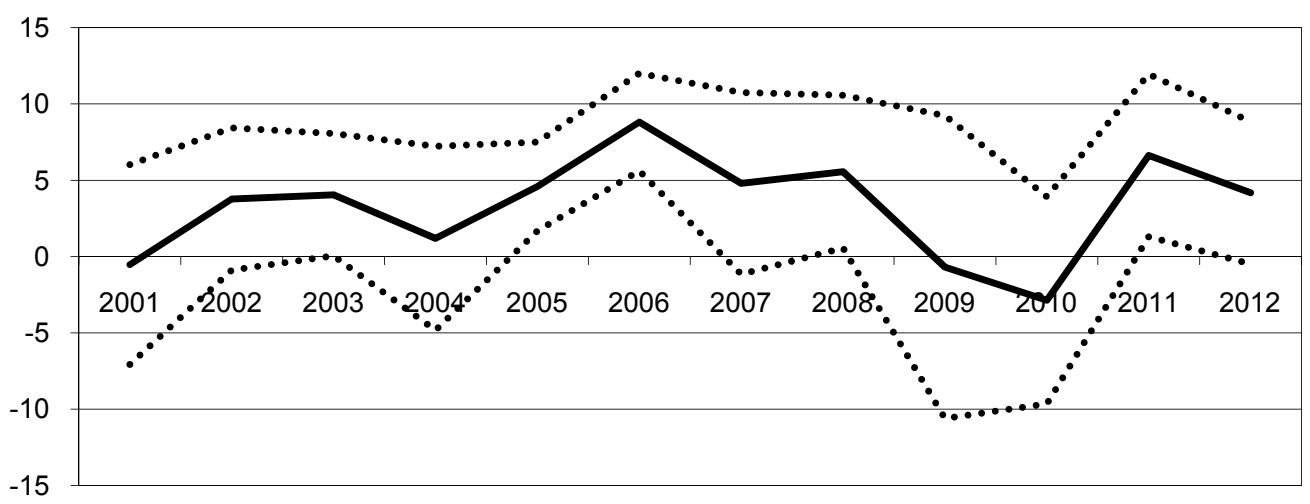

Fig. 1. Marginal effect of the share of post-Soviet trade on economic growth in the regions of Russia, baseline specification

Note: dotted line represents the $5 \%$ confidence intervals.

In order to simplify the exposition, I report the results of the analysis in graphical form. Figure 1 reports the main findings of the baseline regression. It plots the marginal coefficient of the share of the post-Soviet trade obtained for each annual cross-sectional regression alongside with the accompanying 5\% confidence intervals. The results are straightforward: one observes no evidence of a decline in the magnitude or significance of the effect of the post-Soviet trade on growth. The effect first becomes significant in 2003, remains significant in the mid-2000s, disappears during the crisis of 2008-2010 and again becomes significant in 2011. In 2011, the marginal effect is even larger than in early 2000s. It suggests that the hypothesis explaining the positive effects of the post-Soviet trade only by the surviving economic ties and overcoming the problems of disorganization is less likely to fit the data.

Figures 2-5 report the results of the robustness tests. One can see that excluding Moscow, St. Petersburg, Tyumen Oblast or the ethnic republics of the Northern Caucasus does not have any significant effect on the results (if anything, it makes them stronger). Including Chuktoka, Kalmykia and Ingushetia, on the contrary, makes the significant results disappear in almost all years, except 2011 and 2005-2006. Again, I observe no evidence of a decline of the marginal effect of the post-Soviet trade on the economic growth (in terms of statistical or economic significance). 
№ 32018

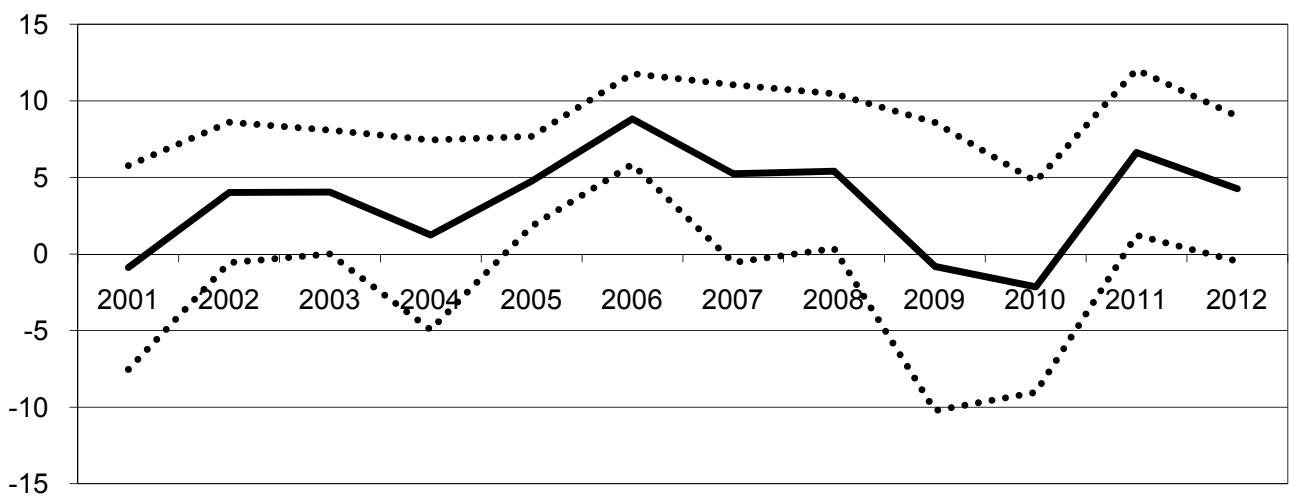

Fig. 2. Marginal effect of the share of post-Soviet trade on economic growth in the regions of Russia, excluding Cities of Moscow and St. Petersburg

Note: here and below dotted line represents the $5 \%$ confidence intervals.

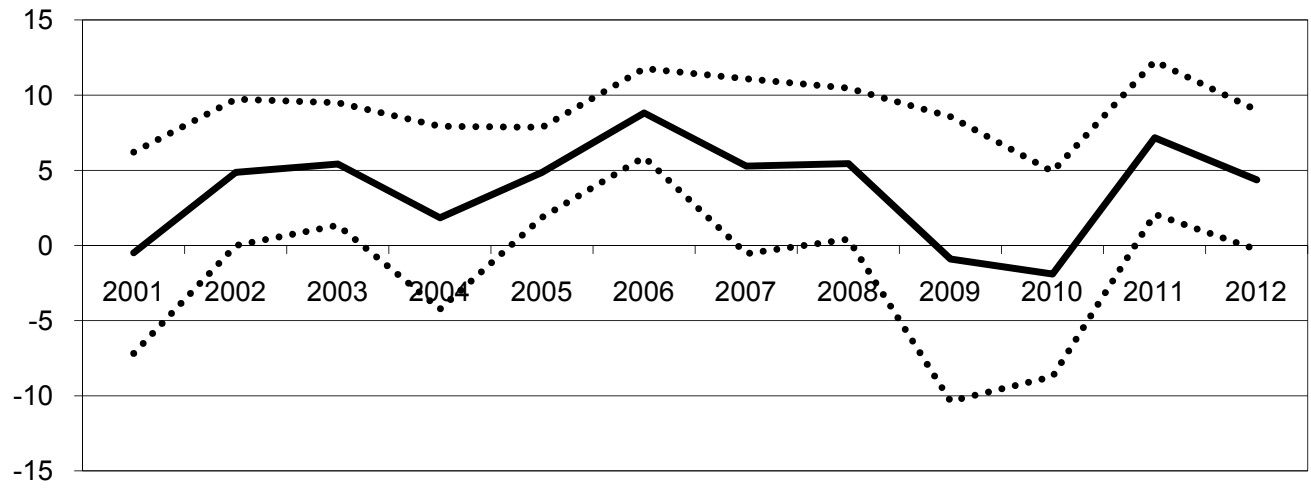

Fig. 3. Marginal effect of the share of post-Soviet trade on economic growth in the regions of Russia, excluding Cities of Moscow and St. Petersburg and Tyumen Oblast

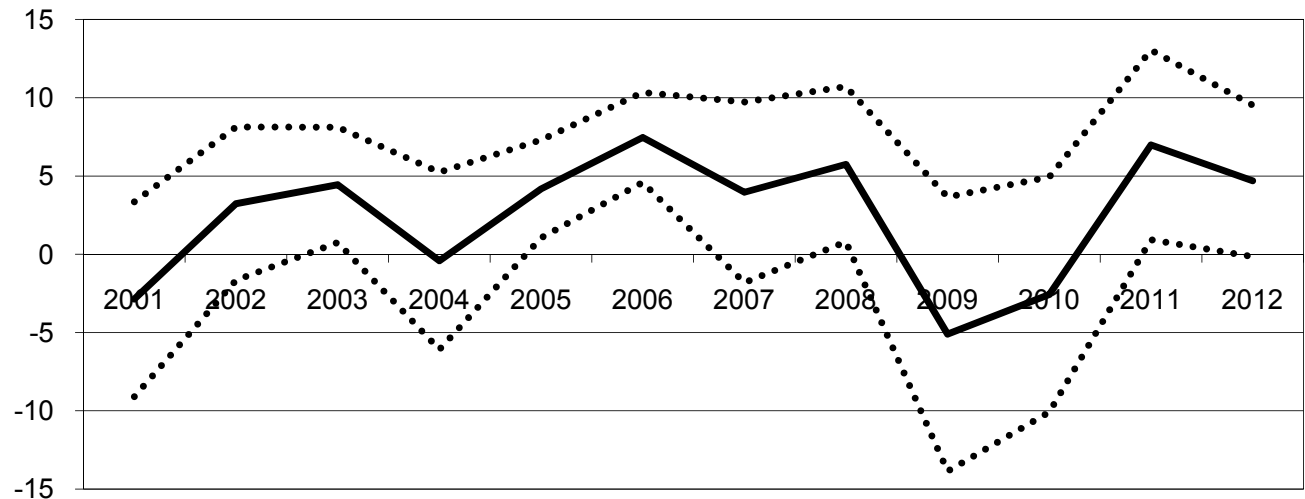

Fig. 4. Marginal effect of the share of post-Soviet trade on economic growth in the regions of Russia, excluding ethnic republics of the Northern Caucasus 


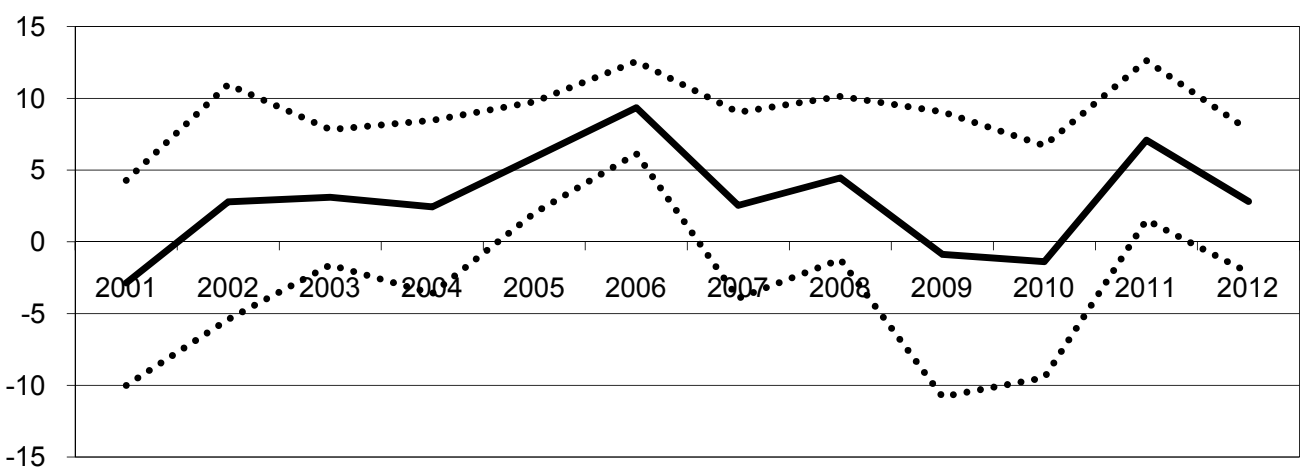

Fig. 5. Marginal effect of the share of post-Soviet trade on economic growth in the regions of Russia, including outliers

\section{DIRECT APPROACH: QUANTITATIVE PROXIES OF ECONOMIC INSTITUTIONS}

In the next step, I proceed to looking at indicators of institutional quality and computing their correlation with the share of trade with post-Soviet countries. In particular, I use six datasets. The first dataset comes from the World Bank. In 2012, this organization made a subnational Doing Business (DB) ranking available, which covers about 30 cities of Russia. The Doing Business approach to measuring institutional quality concentrates on the content of formal law rather than informal business practices. In this paper, I use the city score of the DB as the proxy for the score in the region ${ }^{1}$ and look both at individual components of the DB score (for various aspects of institutional quality) and the aggregate score. The second database comes from the European Bank for Reconstruction and Development's BEEPS dataset. In 2012, the BEEPS survey in Russia was implemented in about 40 regions and was constructed so that in each region a representative sample of companies was surveyed. Based on these data, World Bank published two ratings of regions, looking at the administrative burden (whether firms report various aspects of the regulatory environment and governmental agencies' operations as a burden for them) and the administrative corruption (whether firms report paying bribes to be likely): I apply these aggregated indicators for my analysis (Russian..., 2013).

Four other datasets were generated by the Russian sources. First, I use the data from a survey of small and medium-sized enterprises implemented by OPORA, a large Russian business association, in 2012. OPORA survey was implemented in about 40 regions and ranked them according to administrative climate and

\footnotetext{
${ }^{1}$ Typically, there is only one city in each region included in the database.
} 
security of business (e.g., how the tax authorities and law enforcement operate, how restrictive regulation is, how high administrative barriers are, how high the crime rate is etc.). The second dataset comes from FOM, one of the leading Russian polling agencies. In 2010, it implemented a survey of corruption in almost all regions of Russia. The survey was based on representative samples in each region and attempts to obtain information on corruption experience of households: how likely they are to be requested a bribe, whether they pay a bribe if they are requested and how large the bribe was. Furthermore, the survey also measured the perception of corruption in each region: I use both experienced and perceived corruption indicators. Unlike three preceding indicators, where I look at the ranking of regions, here I look at a particular value of the corruption coefficient reported for the region and varying between zero and one. One more dataset is based on a survey implemented by Transparency International and INDEM in 2002. The survey was conducted in 40 regions and measured experienced and perceived corruption as reported by both companies and households. The last dataset is collected by Ekspert RA, a Russian rating agency, which annually reports an index of Russian regions according to their investment risk, an aggregate indicator capturing both the quality of the regulatory environment and of governance and other aspects of regional development. I look at the value of the investment risk coefficient (between 0 and 1). The indicator is reported for each region of Russia annually; in this paper, I only look at the value of indicator in 2010-2011 (i. e., at the moment of time proximate to that when most other indicator - except the Transparency International/INDEM score - were collected).

The results of the analysis are reported in Table. I correlate the indicators with the share of the post-Soviet trade in the regions in the period the dataset was collected. For the majority of indicators, no significant correlation was found. Some of the results are significant. On the one hand, according to the BEEPS, DB and OPORA indicators, the regions with higher post-Soviet trade also occupy higher place in the rating (i. e., the correlation coefficient between trade and the position in the rating is negative). It means that these regions have better economic institutions in terms of formal regulation, business environment for small and medium-sized companies and administrative burden for business. On the other hand, in 2010 the households of the regions with higher share of post-Soviet trade also reported higher experienced corruption. Hypothetically, the last result could mean that the effect of the post-Soviet trade dependence for business environment may differ from the effect for how public administration interacts with households. The finding for the FOM data, however, holds only if one includes the republics of the Northern Caucasus. If one drops them, the correlation coefficient goes down to 0.157 and becomes insignificant. Essentially, it means that the correlation between corruption measured by the FOM survey 
and the post-Soviet trade share is spurious: regions of the Northern Caucasus have relatively strong trade ties with the post-Soviet countries (it especially applies to Dagestan, which borders Azerbaijan and carries out about $50 \%$ of its foreign trade with the CIS countries) and at the same time have strong endemic corruption.

Therefore, the results of direct analysis of co-movement of the quality of economic institutions and post-Soviet trade also suggest that there is a positive link between these variables. Again, I have to highlight a number of important caveats. First, correlation analysis makes it impossible to measure the ceteris paribus effect of the post-Soviet trade. Second, one has to be extremely cautious while making claims regarding the direction of causality. In case of the post-Soviet trade, as mentioned, in many cases one deals with very long-term historically driven connections going back to the Soviet (or even Tsarist) eras, which makes it more likely that the causal link indeed goes from the trade dependence to the quality of institutions (which emerged only in the 1990s). But, again, the positive effects observed in this study could be associated with the part of the post-Soviet trade, which emerged in the 2000s and follows the market logic: for example, regions with better economic institutions could create better conditions for the development of consumer goods industries, which would then expand to the CIS (either by acquiring new markets or by searching for new sources of inputs - then results of Table actually measure the intra-industry trade effects). However, even in the current form the results suggest at least an interesting co-movement of variables implying the need for further research with better identification strategies.

Table

Share of post-Soviet trade and indicators of institutional quality

\begin{tabular}{l|c|c}
\hline \multicolumn{1}{c|}{ Variable } & $\begin{array}{c}\text { Correlation } \\
\text { coefficient }\end{array}$ & Sample \\
\hline Experienced corruption, FOM, 2010 & $0.217^{*}$ & 69 \\
\hline Perceived corruption, FOM, 2010 & 0.074 & 69 \\
\hline Doing Business (DB), World Bank, 2012a & $-0.352^{*}$ & 29 \\
\hline DB: Starting a businessa & 0.159 & 29 \\
\hline DB: Getting construction permitsa & -0.055 & 29 \\
\hline DB: Getting access to electricitya & $-0.328^{*}$ & 29 \\
\hline DB: Registering propertya & -0.296 & 29 \\
\hline Administrative climate and security, OPORA, 2012a & -0.152 & 39 \\
\hline Administrative burden, BEEPS, 2012a & $-0.339^{* *}$ & 37 \\
\hline Administrative corruption, BEEPS, 2012a & -0.164 & 37 \\
\hline Ekspert Investment Risk, 2010-2011 & 0.113 & 79 \\
\hline Transparency International/INDEM corruption, perceived, 2002 & 0.046 & 40 \\
\hline Transparency International/INDEM corruption, experienced, 2002 & 0.048 & 40 \\
\hline
\end{tabular}

Notes: *** 1\% significance level, ** 5\% significance level, * 10\% significance level; a because the variable is the rank of the region in the ranking, Spearman correlation coefficient applied. 


\section{CONCLUSION}

It remains to summarize the main results of the paper. The goal of the investigation was to understand the impact of the post-Soviet trade on the quality of economic institutions in the regions of Russia. Looking at the period of time between 2001-2012, it appears that the post-Soviet trade has, if any, a positive impact on the institutional quality. There is a substantial variation in both the relative share of the post-Soviet trade in the total international trade turnover and the quality of economic institutions at the subnational level in Russia. The paper finds that Russian regions, which trade more with the post-Soviet countries than with other states of the world, appear to have better economic institutions. On the one hand, the quantitative indicators of the quality of economic institutions at the subnational level exhibit, if any, a positive correlation with the share of post-Soviet trade (with one exception). On the other hand, post-Soviet trade encourages growth in the regions of Russia, and this effect does not go down over time, as one would expect if trade with the post-Soviet countries were driven only by the old inefficient economic dependencies.

This effect could be driven by three factors. First, unlike mostly resourcebased exports to other parts of the world, Russian post-Soviet exports are much more likely to contain a significant share of machinery and equipment. While most of the Russian producers selling their machinery in the post-Soviet Soviet Eurasia are unable to compete internationally and thus would be interested in preserving their privileged access to markets, they may still have stronger preferences for some sort of improvement of institutional quality than the resource exporters (in this case, one deals with the second best as opposed to development of truly internationally competitive industries). Thus, regions, which trade more with the post-Soviet countries, could have more complex economic structure, promoting demand for better economic institutions. Second, post-Soviet trade dependence may result in a segmentation of the regional economy into a rent-based sector with strong political ties and a more open sector of smaller businesses, which would embrace better institutions. Third, and most important, post-Soviet trade actually contains two different types of trade relations: those based on old technological complementarities and infrastructure (and essentially driven by the remaining logic of the planned economy) and those driven by market forces, making postSoviet countries (with their cultural and linguistic similarities to Russia) an attractive target for Russian business.

The last argument poses the most substantial challenge for the research of this paper: given the available data (and especially the fact that one cannot disaggregate the post-Soviet trade at the regional level by industry, since this information is not reported systematically) I cannot distinguish the relative importance of these 'old' 
and 'new' post-Soviet trade ties at the regional level. The analysis of this paper suggests, however, that this distinction should be made and investigated more closely. It creates interesting and important opportunities for further research, which - importantly - has to be carried out not only at the national level, but also at the level of subnational regions of Russia with their vastly different structures of the economy and international trade ties.

\section{REFERENCES}

Apokin A., Gnidchenko A., Sabelnikova E. Potential of Import Substitution and Benefits of Economic Integration: Disaggregated Assessments. Ekonomicheskaya Politika = Economic Policy, 2017, vol. 12, issue 2, pp. 44-71. DOI: 10.18288/1994-5124-20172-02. (In Russian).

Blanchard O., Kremer M. Disorganization. Quarterly Journal of Economics, 1997, vol. 112, issue 4, pp. 1091-1126. DOI: 10.1162/003355300555439.

Bruno R.L., Bytchkova M., Estrin S. Institutional Determinants of New Firm Entry in Russia: A Cross-Regional Analysis. Review of Economics and Statistics, 2013, vol. 95, issue 5, pp. 1740-1749. DOI: 10.1162/REST a 00322.

Dairabayeva K., Ferrantino M.J., Portugal-Perez A., Schmidt G. Export Competitiveness and FDI Performance across the Regions of the Russian Federation. World Bank Policy Research Working Paper 7821, 2016. Available at: http://documents.worldbank. org/curated/en/407151473792036946/pdf/WPS7821.pdf (accessed September 2018).

Donnithorne A. China's Cellular Economy: Some Economic Trends since the Cultural Revolution. China Quarterly, 1972, vol. 52, pp. 605-619. DOI: 10.1017/ S0305741000048116.

Eurasian Economic Integration - 2017. Eurasian Development Bank, 2017. Available at: https://eabr.org/en/analytics/integration-research/cii-reports/eurasian-economicintegration-2017/ (accessed September 2018).

Fidrmuc J. Economic Reform, Democracy and Growth during Post-Communist Transition. European Journal of Political Economy, 2003, vol. 19, issue 3, pp. 583-604. DOI: 10.1016/S0176-2680(03)00010-7.

Gaddy C., Ickes B.W. Stability and Disorder: An Evolutionary Analysis of Russia's Virtual Economy. 1999. Available at: https://deepblue.lib.umich.edu/bitstream/handle/2027. 42/39660/wp276.pdf?sequence=3 (accessed September 2018).

Gel'man V. Regime Transition, Uncertainty, and Prospects for Democratization: The Politics of Russia's Regions in a Comparative Perspective. Europe-Asia Studies, 1999, vol. 51, issue 6, pp. 939-956. DOI: 10.1080/09668139998589.

Granville B. Do Informal Institutions Matter for Technological Change in Russia? The Impact of Communist Norms and Conventions, 1998-2004. World Development, 2010, vol. 38, no. 2, pp. 155-169. DOI: 10.1016/j.worlddev.2009.10.010.

Guriev S., Sonin K. Dictators and Oligarchs: A Dynamic Theory of Contested Property Rights. Journal of Public Economics, 2009, vol. 93, issue 1-2, pp. 1-13. DOI: 10.1016/j. jpubeco.2008.07.003.

Heinrich A. Why Corporate Governance in the Russian Oil and Gas Industry Is Improving. Corporate Governance: International Journal of Business in Society, 2005, vol. 5, issue 4, pp. 3-9. DOI: 10.1108/14720700510616550.

Hidalgo C., Hausmann R. The Building Blocks of Economic Complexity. Proceedings 
of the National Academy of Sciences, 2009, vol. 106, issue 26, pp. 10570-10575. DOI: 10.1073/pnas.0900943106.

Kheyfets B. Eurasian Economic Union: New Challenges for the Business. Obshchestvo $i$ Ekonomika = Society and Economy, issue 6, pp. 5-22 (In Russian).

Kheyfets B. Russian Business in the EurAsEC Countries: A Modernization Aspect. Moscow: Ekonomika. 2011, 294 p. (In Russian).

Lankina T., Libman A., Obydenkova A. Authoritarian and Democratic Diffusion in Postcommunist Regions. Comparative Political Studies, 2016, vol. 49, issue 12, pp. 1599-1629. DOI: 10.1177/0010414016628270.

Ledyaeva S., Karhunen P., Kosonen R. Birds of a Feather: Evidence of Commonality of Corruption and Democracy in the Origin and Location of Foreign Investment in the Russian Regions. European Journal of Political Economy, 2013, vol. 32, pp. 1-25. DOI: 10.1016/j.ejpoleco.2013.06.003.

Libman A. Complementarity of the Economies of Russia and Ukraine: A Regional Aspect. Vestnik Instituta Ekonomiki RAN = Herald of the Institute of Economics RAS, 2013, issue 3, pp. 130-142 (In Russian).

Libman A. Democracy, Size of Bureaucracy, and Economic Growth: Evidence from Russian Regions. Empirical Economics, 2012, vol. 43, issue 3, pp. 1321-1352. DOI: 10.1007/ s00181-011-0525-5.

Libman A., Obydenkova A. International Trade as a Limiting Factor in Democratization: An Analysis of Subnational Regions in Post-Communist Russia. Studies in Comparative International Development, 2014, vol. 49, no. 2, pp. 168-196. DOI: 10.1007/s12116013-9130-2.

Marshall J.B., Stone R.W. Expropriation Risk and Strategic Entry Decisions in Foreign Direct Investment. Working Paper, University of Rochester. 2011.

Obydenkova A., Libman A. Causes and Consequences of Democratization: The Regions of Russia. Abingdon: Routledge, 2015.

Obydenkova A., Libman A. The Impact of External Factors on Regime Transition: Lessons from the Russian Regions. Post-Soviet Affairs, 2012, vol. 28, issue 3, pp. 346-401. DOI: 10.2747/1060-586X.28.3.346.

Polterovich V. Institutional Traps and Economic Reforms. Ekonomika i Matematicheskie Metody = Economics and Mathematic Methods, 1999, vol. 35, issue 2, pp. 1-37 (In Russian).

Poncet S., de Waldemar F.S. Export Upgrading and Growth: The Prerequisites of Domestic Embeddedness. World Development, 2013, vol. 51, pp. 104-118. DOI: 10.1016/j. worlddev.2013.05.010.

Rodrik D. What's So Special about China's Exports? China and World Economy, 2006, vol. 14, issue 5, pp. 1-19. DOI: 10.1111/j.1749-124X.2006.00038.x.

Russian Federation: National and Regional Trends in Regulatory Burden and Corruption. World Bank, 2013. Available at: http://documents.worldbank.org/curated/ en/584111468092953347/Russian-Federation-National-and-regional-trends-inregulatory-burden-and-corruption (accessed September 2018).

Sandholtz W., Koetzle W. Accounting for Corruption: Economic Structures, Democracy and Trade. International Studies Quarterly, 2000, vol. 44, issue 1, pp. 31-50.

Stoner-Weiss K. Foreign Direct Investment and Democratic Development in the Russian Provinces: A Preliminary Analysis. Policy Studies Journal, 2000, vol. 28, issue 1, pp. 96-113. DOI: 10.1111/j.1541-0072.2000.tb02017.x.

Tansey O., Koehler K., Schmoltz A. Ties to the Rest: Autocratic Linkages and Regime Survival. Comparative Political Studies, 2017, vol. 50, issue 9, pp. 1221-1254. DOI: $10.1177 / 0010414016666859$. 
Vardomskiy L. Post-Soviet Integration and Economic Growth in New Borderland of Russia in 2005-2015. Prostranstvennaya Ekonomika = Spatial Economics, 2017, issue 4, pp. 23-40. DOI: 10.14530/se.2017.4.023-040. (In Russian).

Yakovev E., Zhuravskaya E. The Unequal Enforcement of Liberalization: Evidence from Russia's Reform of Business Regulation. Journal of the European Economic Association, 2013, vol. 11, issue 4, pp. 808-838. DOI: 10.1111/jeea.12026.

Yevsigneev V. Monetary Integration in the EU and in the CIS: A Comparative Semantic Analysis. Moscow: Nauka, 1997, 271 p. (In Russian).

\title{
ПОСТСОВЕТСКАЯ ТОРГОВЛЯ И КАЧЕСТВО ИНСТИТУТОВ: РЕГИОНАЛЬНЫЙ АНАЛИЗ
}

\begin{abstract}
А. Либман
Либман Александр Михайлович - доктор экономических наук, $\mathrm{PhD}$ (Economics), профессор восточно-европейских исследований. Мюнхенский университет. Konradstraße 6, 80801 Munich, Germany. E-mail: alexander.libman@soziologie.uni-muenchen.de.

ORCID: 0000-0001-8504-3007

Аннотация: В статье исследуется влияние постсоветской торговли на качество экономических институтов в регионах России. В работе используются два подхода: 1) изменение влияния постсоветской торговли на рост с течением времени (исходя из предположения, что если этот эффект со временем сокращается, воздействие постсоветской торговли на рост связано преимущественно с наследием советской экономики и, следовательно, едва ли содействует росту качества институтов); 2) корреляция постсоветской торговли и количественных показателей качества экономических институтов. Полученные результаты позволяют сделать вывод о том, что постсоветская торговля, скорее всего, оказывает положительное воздействие на трансформацию институтов. В частности, показано, что регионы России, где доля постсоветской торговли в совокупном обороте внешней торговли выше, характеризуются устойчиво более высокими темпами экономического роста в период нашего исследования (2001-2012 гг.). Помимо этого, количественные показатели качества институтов в регионах России характеризуются положительной корреляцией с постсоветской торговлей. С теоретической точки зрения, полученные результаты могут быть обусловлены более высоким уровнем сложности региональных экономик и существенной ролью новых, основанных на рыночных принципах, связей в структуре постсоветской торговли.
\end{abstract}

Ключевые слова: внешняя торговля, качество институтов, постсоветское пространство, регионы России

\section{СПИСОК ЛИТЕРАТУРЫ}

Апокин А., Гнидченко А., Сабельникова Е. Потенциал импортозамещения и выгоды от экономической интеграции: дезагрегированные оценки // Экономическая политика. 2017. Т. 12. № 2. С. 44-71. DOI: 10.18288/1994-5124-2017-2-02.

Вардомский Л.Б. Постсоветская интеграция и экономический рост нового приграничья России в 2005-2015 гг. // Пространственная экономика. 2017. № 4. С. 23-40. DOI: $10.14530 /$ se.2017.4.023-040. 
Евстигнеев В.Р. Валютно-финансовая интеграция в ЕС и СНГ: Сравнительный семантический анализ. М.: Наука, 1997. 271 с.

Либман А.М. Комплементарность экономики России и Украины: региональный аспект // Вестник Института экономики РАН. 2013. № 3. С. 130-142.

Полтерович B.M. Институциональные ловушки и экономические реформы // Экономика и математические методы. 1999. Т. 35. № 2. С. 1-37.

Хейфеи Б.А. Евразийский экономический союз: новые вызовы для бизнеса // Общество и экономика. 2015. № 6. С. 5-22.

Хейфеи Б.А. Российский бизнес в странах ЕврАзЭС: модернизационный аспект. М.: Экономика, 2011. 294 с.

Blanchard O., Kremer M. Disorganization // Quarterly Journal of Economics. 1997. Vol. 112. Issue 4. Pp. 1091-1126. DOI: 10.1162/003355300555439.

Bruno R.L., Bytchkova M., Estrin S. Institutional Determinants of New Firm Entry in Russia: A Cross-Regional Analysis // Review of Economics and Statistics. 2013. Vol. 95. Issue 5. Pp. 1740-1749. DOI: 10.1162/REST_a_00322.

Dairabayeva K., Ferrantino M.J., Portugal-Perez A., Schmidt G. Export Competitiveness and FDI Performance across the Regions of the Russian Federation. World Bank Policy Research Working Paper 7821. 2016. URL: http://documents.worldbank.org/curated/ en/407151473792036946/pdf/WPS7821.pdf (дата обращения: сентябрь 2018).

Donnithorne A. China's Cellular Economy: Some Economic Trends since the Cultural Revolution // China Quarterly. 1972. Vol. 52. Pp. 605-619. DOI: 10.1017/ S0305741000048116.

Eurasian Economic Integration - 2017 / Eurasian Development Bank. 2017. URL: https://eabr.org/en/analytics/integration-research/cii-reports/eurasian-economicintegration-2017/ (дата обращения: сентябрь 2018).

Fidrmuc J. Economic Reform, Democracy and Growth during Post-Communist Transition // European Journal of Political Economy. 2003. Vol. 19. Issue 3. Pp. 583-604. DOI: $10.1016 / \mathrm{S} 0176-2680(03) 00010-7$.

Gaddy C., Ickes B.W. Stability and Disorder: An Evolutionary Analysis of Russia's Virtual Economy. 1999. URL: https://deepblue.lib.umich.edu/bitstream/handle/2027.42/39660/ wp276.pdf?sequence=3 (дата обращения: сентябрь 2018).

Gel'man V. Regime Transition, Uncertainty, and Prospects for Democratization: The Politics of Russia's Regions in a Comparative Perspective // Europe-Asia Studies. 1999. Vol. 51. Issue 6. Pp. 939-956. DOI: 10.1080/09668139998589.

Granville B. Do Informal Institutions Matter for Technological Change in Russia? The Impact of Communist Norms and Conventions, 1998-2004 // World Development. 2010. Vol. 38. No. 2. Pp. 155-169. DOI: 10.1016/j.worlddev.2009.10.010.

Guriev S., Sonin K. Dictators and Oligarchs: A Dynamic Theory of Contested Property Rights // Journal of Public Economics. 2009. Vol. 93. Issue 1-2. Pp. 1-13. DOI: 10.1016/j.jpubeco.2008.07.003.

Heinrich A. Why Corporate Governance in the Russian Oil and Gas Industry Is Improving // Corporate Governance: International Journal of Business in Society. 2005. Vol. 5. Issue 4. Pp. 3-9. DOI: 10.1108/14720700510616550.

Hidalgo C., Hausmann R. The Building Blocks of Economic Complexity // Proceedings of the National Academy of Sciences. 2009. Vol. 106. Issue 26. Pp. 10570-10575. DOI: 10.1073/pnas.0900943106.

Lankina T., Libman A., Obydenkova A. Authoritarian and Democratic Diffusion in Postcommunist Regions // Comparative Political Studies. 2016. Vol. 49. Issue 12. Pp. 1599-1629. DOI: 10.1177/0010414016628270.

Ledyaeva S., Karhunen P., Kosonen R. Birds of a Feather: Evidence of Commonality of 
Corruption and Democracy in the Origin and Location of Foreign Investment in the Russian Regions // European Journal of Political Economy. 2013. Vol. 32. Pp. 1-25. DOI: 10.1016/j.ejpoleco.2013.06.003.

Libman A. Democracy, Size of Bureaucracy, and Economic Growth: Evidence from Russian Regions // Empirical Economics. 2012. Vol. 43. Issue 3. Pp. 1321-1352. DOI: 10.1007/ s00181-011-0525-5.

Libman A., Obydenkova A. International Trade as a Limiting Factor in Democratization: An Analysis of Subnational Regions in Post-Communist Russia // Studies in Comparative International Development. 2014. Vol. 49. No. 2. Pp. 168-196. DOI: 10.1007/s12116013-9130-2.

Marshall J.B., Stone R.W. Expropriation Risk and Strategic Entry Decisions in Foreign Direct Investment. Working Paper, University of Rochester. 2011.

Obydenkova A., Libman A. Causes and Consequences of Democratization: The Regions of Russia. Abingdon: Routledge, 2015.

Obydenkova A., Libman A. The Impact of External Factors on Regime Transition: Lessons from the Russian Regions // Post-Soviet Affairs. 2012. Vol. 28. Issue 3. Pp. 346-401. DOI: $10.2747 / 1060-586 X .28 .3 .346$.

Poncet S., de Waldemar F.S. Export Upgrading and Growth: The Prerequisites of Domestic Embeddedness // World Development. 2013. Vol. 51. Pp. 104-118. DOI: 10.1016/j. worlddev.2013.05.010.

Rodrik D. What's So Special about China's Exports? // China and World Economy. 2006. Vol. 14. Issue 5. Pp. 1-19. DOI: 10.1111/j.1749-124X.2006.00038.x.

Russian Federation: National and Regional Trends in Regulatory Burden and Corruption. World Bank. 2013. URL: http://documents.worldbank.org/curated/en/ 584111468092953347/Russian-Federation-National-and-regional-trends-in-regulatoryburden-and-corruption (дата обращения: 2018).

Sandholtz W., Koetzle W. Accounting for Corruption: Economic Structures, Democracy and Trade // International Studies Quarterly. 2000. Vol. 44. Issue 1. Pp. 31-50.

Stoner-Weiss K. Foreign Direct Investment and Democratic Development in the Russian Provinces: A Preliminary Analysis // Policy Studies Journal. 2000. Vol. 28. Issue 1. Pp. 96-113. DOI: 10.1111/j.1541-0072.2000.tb02017.x.

Tansey O., Koehler K., Schmoltz A. Ties to the Rest: Autocratic Linkages and Regime Survival // Comparative Political Studies. 2017. Vol. 50. Issue 9. Pp. 1221-1254. DOI: 10.1177/0010414016666859.

Yakovev E., Zhuravskaya E. The Unequal Enforcement of Liberalization: Evidence from Russia's Reform of Business Regulation // Journal of the European Economic Association. 2013. Vol. 11. Issue 4. Pp. 808-838. DOI: 10.1111/jeea.12026. 